\title{
Research on Art Education and Cultivation of College Students' Innovative Ability
}

\author{
Dan Zhang ${ }^{1, \text { a }}$ \\ ${ }^{1}$ School of Art, Qingdao University of Science and Technology, Qingdao266000, China \\ aqdzhangdan@163.com
}

Keywords: Art education, innovative ability, big data, artistic quality, comprehensive quality

\begin{abstract}
In this paper,the studies on how to enhance the quality of creative education in the cultivation of college students in the information age are conducted.Nowadays, the education of college students not only focus on the development of comprehensive ability, but also pay attention to the cultivation of innovative ability. Art education is an important component of comprehensive ability cultivation, and it is also the main source of college students' innovative ability. The information age puts forward new requirements to college students' art education, and also provides new opportunities and challenges. By combining the new social media tools and the practice of art education, we can not only improve the quality of college art education and the comprehensive quality of college students, but also can cultivate the innovative ideas of college students, so as to improve the quality of creative talents cultivation.
\end{abstract}

\section{Introduction}

With the development of market economy, the influence of utilitarianism makes art education in colleges and universities weak to a certain degree. At the same time, the attention to exam-oriented education and the increase of basic courses and professional courses in college further undermine the humanities curriculum, thus leading to the long-term emphasis on single professional and technical education in our colleges and universities and leading to ignoring the cultivation of students' artistic quality. President of Harvard University, Lawrence Summers made a speech in BeiJing University of "The Impact of Globalization on Higher Education," argues that undergraduate education should pay more attention to art education and human quality in the tide of globalization. In the undergraduate education, the comprehensive quality cultivation is inseparable from the art education. All kinds of artistic experience on the formation of students have positive impact, and enrich the individual's ideology. It has been proved that it needs artistic influence to achieve the scientific education and humanities education on the cultivation of innovative talents in colleges and universities.Art education plays a very important role in cultivating college students' innovation ability.

Art and science are mutually permeable and interactive, and art education plays an important role in cultivating creative talents. Art education can help develop the right brain EQ, training and development of human image thinking ability, thereby enhancing human creativity.

In the process of talent development, art education is an important way to improve the ideological quality of innovative talents. It is also an important way to cultivate innovative talents. It is also an important way to cultivate the innovative ability of compound talents and realize the integration of science education and humanistic education. Therefore, colleges and universities should pay attention to the role of art education to achieve the spirit of innovation and innovation ability of talent.

\section{Domestic and international research status and development trends}

As a visiting scholar at Massachusetts Institute of Technology, the author have had a profound study of the world's top universities' art education courses and mechanisms, such as Harvard University, Massachusetts Institute of Technology, Stanford University. The top American universities not only focus on the development of comprehensive ability of students' education,but also pay more attention to the cultivation of innovation ability. These top universities believe that 
science education and art education are main aspects of comprehensive ability development, and also could cultivate students' innovation ability. The top colleges and universities in the United States are increasingly applied to the practice of education and teaching, and have achieved very good results.

The lack of art education is precisely the current problems of art education in China colleges and universities; the domestic art education research for college students to improve the overall quality, especially the innovation capacity of the research is not in-depth.It shows that the research of educational application is on the rise through literature research, the attention is increasing year by year. However, Chinese college art education is still regarded as an unimportant part. In fact, art education and science education play an irreplaceable role in the overall quality of contemporary college students.

2.1 In practical teaching, some universities are still teaching-oriented, and can not use data science methods and tools to analyze and study the connotation of art education, focusing only on the specific knowledge of art education teaching.

2.2 The teaching methods can not meet the requirements in the information age. The information technology and data knowledge of the existing teacher is not enough, and teaching ways are obsolete. At present, we are faced with unconventional undergraduates who are born after 1995 and pursue the individuality and self, life and the high degree of integration of the network. If you want to teach them the Chinese art education, we must understand them and adopt innovative methods which they can accept and recognize, so as to have the real impact on them and achieve the purpose of education.

2.3 Art teaching is not from the overall quality of students, and teaching design is short of systematic. Art education and other disciplines of education are not a good fusion as a whole; many courses related to art education do not have a general teaching guide, and the courses and teachers teaches according to their own understanding. Art education looks more fragmented and casual which is lack of systematic for students.

Therefore,there is a greater space for development to study and excavation of art education deeply in higher education. How to construct the content system of art education course and integrate them into different sections and disciplines, and how to improve the teaching level of teachers in the information age is still a prominent problem in art education.

\section{The fusion of the arts education and innovative development in colleges and universities}

Art education is an important aspect of comprehensive education for college students, and an indispensable content for cultivating high quality talents. The purpose of higher education is not only to enable students to learn professional knowledge to become a means of survival, more importantly, is to enable students to fully grow and become a complete personality of the people. In the process of talent cultivation,colleges and universities need to establish the basic position of art education, to improve the art education, to supplement the students' knowledge structure, to enhance the aesthetic ability, to develop the intelligence, and to cultivate innovative thinking, so that art education permeates into the whole process of talent cultivation. We have to pay attention to promoting the development of the comprehensive quality in talent cultivation.

\subsection{Explore the general art education in colleges and universities}

According to the characteristics of talent cultivation of average university students, colleges and universities should understand and grasp the position and function of art education correctly in the construction of university teaching system, and design art general education courses. Art general education is an important way to improve the quality of compound talents in colleges and universities. It will help to improve and supplement the students 'knowledge structure as well as improve students' aesthetic cultivation and inspire students' positive spirit. Thus, art general education plays an important role in the formation of innovative talents and the upgrading of ideological quality.

\subsection{Use the new information tool}

Art education is faced to a certain college students with cultural foundation and life skills who have active thinking and a strong ability to accept new things. So college art education teachers should use Mocc, Wechat, QQ and other forms. It can not only make their art atmosphere better, but 
also attract more students to participate in art education by the communication function of the information tools .At the same time, innovative learning atmosphere, good teacher-student interaction, and a large number of peers in different network platform learning can stimulate student initiative and creativity.

Wechat platform is in the form of "micro-reading" to transmit traditional cultural information to the audience. By analyzing the data of the discussion of the topic and the forwarding of the contents, the colleges and the teachers can find the interesting point and the content of the students' users. So they can make full use of the traditional functions of the mobile media to take a number of new technologies to boost art education strongly.

The network platforms are equal, interactive and with strong participation. They also have a strong characteristic of the information age, and are popular with college students. Young students immersed in them that will stimulate their own creativity and take the initiative to play the knowledge and skills they have learned, leading to the practice of their ability to create new products.

\subsection{Make use of data information}

With the continuous accumulation of educational data and in-depth development, data will have a profound impact on art education. Today, we are opening a large-scale production, sharing and application of data era. The Internet and new media evolved into a two-way selection process, the audience can be judged according to their own preferences, views and choices, rather than the spread of the previous single-dimensional way. Most of today 's university art education still stay in the classroom to explain the basic stage of artistic knowledge, which has been unable to meet contemporary college students requirements that improve artistic quality and the overall quality. Combined with the characteristics of the dissemination of cultural and artistic information in today's information age, art education will be integrated into the daily life of college students, thus imperceptibly enhance the overall quality of college students, and truly improve the quality of higher education.

\section{Conclusions}

Art education is an important way to cultivate talents' innovation ability. Innovation is the inexhaustible motive force of national progress. Creative talents are the source of social development. Innovative talents should not only have innovative spirit, innovative knowledge, but also integrated cultural quality, professional quality and humanistic quality. For college students, innovation is to cultivate students rich imagination and logical thinking ability, so that it can find problems in practical work, and find a solution to the problem, finally complete a new invention or produce a new outcome by practice. Therefore, the creation of art education courses in colleges and universities, so that students are subject to new stimuli, thinking about new issues, the spark of the creation, the singular imagination, and transfer knowledge to real creativity. So as to promote the cultivation of students' innovation consciousness and improve the innovation ability.

\section{Acknowledgments}

This work was financially supported by China Scholarship Council(No.201507890018),the special Project of art education of Shandong Province "Research on the importance of cultivation of innovative talents in universities" and the special Project of women and traditional culture of Shandong Province "The inheritance and development of architecture in her perspective" (zx2015018) .

\section{References}

[1] Rogoff, Jonah :Public art in Massachusetts : an analysis of municipal-based practices and approaches (2014) 
[2] Oen, Karin Grace:Admonition and the academy : installation, video, and performance art in Reform Era China

[3] Wong, Yi Lin; Siu, Kin Wai Michael:Fostering creativity from an emotional perspective: Do teachers recognise and handle students' emotions? (2014)

[4] Verschooren, Karen A:art : situating Internet art in the traditional institution for contemporary art (2007)

[5] Information on http://en.cnki.com.cn/ 